\title{
Samosir Regency in the Development of Monument
}

\author{
Corry $^{1}$, Resna Napitu ${ }^{2}$, Supsiloani ${ }^{3}$, Ulung Napitu ${ }^{1}$ \\ ${ }^{I}$ Faculty of Teacher Training and Education, Universitas Simalungun, Indonesia \\ ${ }^{2}$ Faculty of Economic, Universitas Simalungun, Indonesia \\ ${ }^{3}$ Anthropology Study Program, Universitas Negeri Medan, Indonesia \\ purbacorry470@gmail.com
}

\section{Abstract}

This study aims to discuss the development of monument in Samosir Regency, North Sumatra, Indonesia by using a descriptive analytic method with a phenomenological approach. The phenomenological approach is a tradition of qualitative research that is rooted in philosophical and psychological, and focuses on the experience of human life (sociology). The results of this study indicate that there are so many public opinions regarding the development of the monument carried out by Toba Batak community in Samosir Regency. However, the development of this monument is inseparable from two aspects, namely in terms of religion / belief and cultural aspects. The development of monument that is so fierce in Samosir Regency carries so many meanings behind the monument itself. The number of parsadaan's monument in Samosir Regency is 19.

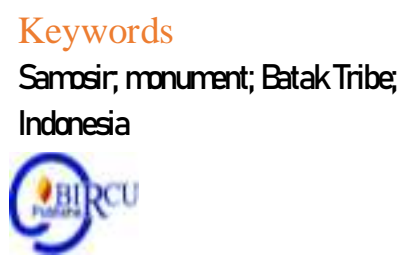

\section{Introduction}

Toba Batak tribe from ancient times until today still retains the traditional values inherited from their ancestors, although sometimes they are contrary to religious teachings but are still maintained. Therefore it is important that there is a process of adaptation, acculturation of socio-cultural values with religion that is adapted to today's life.

The cultural phenomenon of monument development, (Tambak $\mathrm{Na}$ Timbo) and mangongkal holi event is one of Toba Batak traditions that still survive and are maintained today in the area of origin (Bonani Pasogit) and in overseas areas (parserakan). These traditions persist because of the strong cultural, cosmological and religious roots of Toba Bataks that affect the cognition of those who still live in their home areas and those who live in overseas areas. Toba Batak tribe who settled in the area of origin and who settled overseas are a unified whole system in carrying out traditional ceremonies, building tambak na timbo and other ritual ceremonies (Pelly, 1993: 30).

Such traditional and cosmological beliefs encourage Toba Batak tribe to build a monument (stone ponds napir) as a place to live in begu, sumagot and sombaon calmly and comfortably, even though Toba Batak tribe has lived in modern nature and have adopted a religion. Sidjabat (2003: 16) states that Toba Batak tribe tried to build a monument (tambak na timbo) or stone napir giving an indication:

a. Increased economic capacity (hamoraon) of Toba Batak tribe in overseas areas; and the dignity of the clan (self-esteem) of his brother in the area of origin;

b. Clan or family unifier;

c. Respect for ancestors and parents who have died;

d. Expect multiple blessings from ancestors who have died and have been put into a monument (tambak na timbo);

e. Not fully believing in religion and prioritizing adat; 
f. The failure of the church in carrying out its mission led to the rise of ancestor worship for Toba Bataks.

This study aims to analyze Samosir Regency in the Development of Monument in depth, comprehensively and holistically in the life of the modern Toba Batak people who have embraced religion today.

\section{Review of Literature} due:

Factors that supporting the development of Tambak Na Timbo (Monument) are likely

a. The status of competition among fellow Bataks is a factor in the grandeur of Tambak Na Timbo and the luxury of the party that is united with the development of Tambak $\mathrm{Na}$ Timbo. Tambak Na Timbo built by the clan group provoked the envy of other clans until they were able to do the same thing. Successful people in Medan as well as in Jakarta showed their wealth in their hometowns by building a very magnificent Tambak $\mathrm{Na}$ Timbo with a motive for arrogance, arrogance and doing so to elevate the dignity and status of clans / lineages (Bruner, 1987: 139).

b. The monument was built and mangongkal holi-holi party was held lively so that parents were respected (Sangap). This is in accordance with the obligation of adherents of Christianity to respect father and mother and universal respect for people who have died.

c. The development of the Monument reflects a contact between the rich and the poor, the villagers and the City people, young people and the elderly from a lineage. The development of the monument or Tambak Na Timbo basically transfers wealth from the rich to the villagers. Even more fundamentally, rich people and poor people can all respect those who have died.

d. The Monument party especially the ritual party which is put together is to consolidate and strengthen the bond of lineage and the identity contained therein is not eroded. This activity has a role in bridging the perceived discrepancies between the ideal pictures of Toba Batak people. The Monument or Tambak Na Timbo Bridge is a bridge to the past and present and brings back the Batak people to the past aspects of their own historical experiences and their families.

e. That the initial idea of the funeral of the ancestors back in Tambak $N a$ Timbo beautiful and majestic comes from the people in power (influential) of the clan descent because it is considered to increase the dignity and self-esteem of the clan or heredity (Reid, 2002: 188-192 )

The importance of the development of Tambak Na Timbo because there are still many Bataks who believe that ancestral spirits can cause various dangers for close relatives if they do not carry out rituals properly and if ancestral bones are not properly placed in Tambak Na Timbo. They must carry out prayers - prayer of worship and offerings for the ancestors, because it will add sahala and elevate them to be able to sow blessings to those who are still alive (Reid, 2002: 93).

The monument is a refraination of respect for ancestors, as well as consolidating and strengthening the lineage and identity contained therein. Therefore the meaning of the monument as a grave container still has compatibility with the meaning of the grave container in the past. Changes in symbols in the religious procession (Panangkok Saringsaring) indicate the existence of religious symbols that change.

Other research related to the development of the monument as well as the meaning of religiosity under the title Sarcophagus Glance on Samosir Island, Taufiqurrahman 
Setiawan (2014) explains as follows. Most of the sarcophagus found is a communal tomb container (shared) in which there are skulls of many individuals who belong to one clan. In general Samosir Sarcophagus has a rectangular shape and at the top widened, shaped like a boat as a symbol of the vehicle of the dead to the spirit world (Setiawan, 2014: 239).

Referring to the view of Immanuel Kant (1724-1804), which states that everything consists of numerology (ideas, concepts or thoughts) and phenomenology (congress objects, material that can be touched). Both of these are also found in the teachings of Christianity, religious teachings other and other beliefs. In culture universally the two things above (nemonology and phenomenology) are also found in Toba Batak culture.

When the religious life that exists in the Batak land brought by evangelists from Europe brought a flow of Fietism, which is to teach the Batak tribe to live holy and holy spiritually and try to separate themselves from their daily lives. This doctrine of dietism eliminates its culture and uses European culture to fill its daily life. This gave rise to a reaction or resistance to cultural nationalism, namely that the church wanted to eradicate Toba Batak culture and display western culture in their daily lives. At that time Toba Batak tribe sought to understand Christianity and Toba Batak culture together. It was at this time that Toba Batak culture emerged to build a monument (tambak na timbo). Therefore the development of the monument is a phenomenology and has a phenomenology.

The assumption underlying this study is that the meaning of the development of the monument can be found subjectively, if this action is examined in depth, breaking through everything that is behind the visible phenomenon, in accordance with the experience of the clans that have carried out the development of the monument. The phenomenology put forward by Schurtz teaches that each individual is present in the stream of consciousness that is obtained from the process of reflection on everyday experiences. Assuming the reality of other people who are mediated by ways of thinking and feeling, reflecting the past is passed on to others through social relations (Campbell, 1994: 235). That the social world is an intersubjective and meaningful experience. Phenomenology emphasizes the meaning of action, identical with the motives that drive one's actions (older-to motive). Thus to understand individual human actions must be seen from the motives that underlie these actions. Furthermore Schutz added that with the motives underlying the actions or because of motives we can see the meaning of actions in accordance with the original motives that are true underlying the actions carried out individually (Water, 1994: 33).

Berger (1966) further states that, assessment is closely related to his concept of the development of social reality which he considers depends on the position of the individual as a subject. Thus the initial assumptions of thought are related to functional structural. Meaning is produced by the subjective relationship of individuals with the objective world (Brower, 1983: 64). In the process, Berger believes the existence of the dialectic of the three moments experienced by individuals in society, namely externalization, internalization and objectivity, where all three show the existence of individuals as products of society and vice versa of society as individual products. Luckman (1990), asserts that:

1. Humans have the freedom to express themselves without being bound by the structure in which they are

2. Religion is a form of culture as a cultural construction

3. Social reality is the result of a social development created by humans themselves

4. Social development is built in 2 ways, namely:

a. Defining reality or knowledge and knowledge, these two terms are key to the theory of social construction 
b. To examine something intersubjective, Berger uses Durkheim's paradigm of objectivity and Weber's paradigm of subjectivity.

Starting from the fact that the phenomenon and meaning of the development of Monument in Toba Batak community is a form of freedom of Toba Batak tribe to carry out improvisation of the appreciation of traditional values based on the social reality behind the real phenomena and hidden meanings that require in-depth understanding and comprehensive analysis and holistic. That the meaning of the development of monument among Toba Batak tribe can be found subjectively if this action is examined in depth, breaking through everything that is behind the visible phenomenon.

\section{Research Methods}

This research uses descriptive analytic method with phenomenology approach. The phenomenological approach is a tradition of qualitative research that is rooted in philosophical and psychological, and focuses on the experience of human life (sociology). The phenomenological approach is almost similar to the hermeneutics approach which uses life experience as a tool to better understand the social cultural values or historical context in which the experience took place. The nature of qualitative research that is relevant to the phenomenological methodology that distinguishes it from ordinary qualitative research is:

1. Exploring values in human experience and life.

2. The focus of the research is on the whole not on the parts that make up the whole.

3. The purpose of the research is to find the meaning and nature of the experience, not just to search for an explanation or to find measurements of reality.

4. Obtain a picture of life from a first-person perspective through formal and informal interviews.

5. The data obtained is the basis for scientific knowledge to understand human behavior.

6. Questions made reflect the interests, involvement and personal commitment of the researcher.

7. Seeing experience and behavior as a unity that cannot be separated between subject and object or between parts of the whole (Creswell, 1998: 86).

The characteristics of qualitative research using the phenomenological method are as follows:

1. Focus on something that appears, back to the truth, out of routine, and out of what is believed to be the truth and habits in daily life.

2. Phenomenology is interested in the whole, by observing entities from various perspectives and perspectives, until an essential view of the observed phenomena is obtained.

3. Phenomenology seeks the meaning and nature of appearances with intuition and replication in conscious action through experience.

4. Phenomenology describes the experience, not explaining or analyzing it.

5. Phenomenology is rooted in questions that are directly related to the meaning of the observed phenomenon.

6. Integration of subject and object.

7. Investigations carried out within an intersubjective framework, reality is one part of the overall process.

8. Data obtained (through thinking, intuition, replication and judgment) become the main evidence in scientific knowledge. 
9. Research questions must be chosen very carefully so that they can show the main meaning (Moustakes, 1994: 104-120).

The reason for using this research method and technique is because the problem studied concerns the phenomenon and meaning of the development of monument in the life of Toba Batak tribe in Samosir Regency. Through a phenomenological approach, it is hoped that descriptions of phenomena that appear on the ground can be interpreted, their meanings and contents deeper.

Researchers in the phenomenological view try to understand the meaning of events and their relation to ordinary people in certain situations. Phenomenological sociology is basically strongly influenced by the views of Edmund Husserl and Alfred Schultz. Another influence comes from Weber who put pressure on versteheen, namely interpretive understanding of human understanding. Phenomoenology does not assume that researchers know the meaning of something to the people being studied.

\section{Discussion}

\subsection{Samosir in the Development of the Monument}

The cultural and religious roots of the monument development tradition (tambak na timbo) in the life of Toba Batak tribe are traditional religions that believe in a higher lord is mula jadi na bolon (great beginnings) which created the heavens and under the earth (Parkin, 1978: 152). Religious life is centered on the spirits of the ancestors and the way of pleasing the spirits of the ancestors especially men always influences life (Hasselgren, 2008: 67). Toba Batak tribe must respect the spirits of the ancestors with offerings, worship and sacrifice so that the spirits of the ancestors bless them and not disturb them. For this reason, large rituals are carried out through anesthesia accompanied by music or gondang with festive events (Wharcheck, 1907: 67 - 95). The principle of human life or tondi is believed to continue after death. Therefore the traditional funeral program becomes very important because the ancestral spirit marks the beginning of the tondi journey to the realm of death (Hasselgren, 2008: 67-68). On this occasion representatives of three clans joined in dalihan na tolu relatives must be present to carry out the correct rites performed.. After the funeral was buried in the ground for two years, the ancestral bones were dug up again, cleaned and placed in ruma-ruma that were often placed in the yard of the house before carrying out the panakkok saring ceremony in a monument (Warcheck, 1907: 73).

The religious phenomenon, if related to the discovery of the monument development tradition in the life of Toba Batak people with the religious roots of the traditional Batak religion, illustrates the acculturation between the original religious system and the monotheistic religion that has been adopted by the majority of Toba Bataks. This tradition is still found in the lives of Toba Batak people in Samosir Regency and other Regency divisions of the North Tapanuli Regency.

Samosir Regency is one of the most unique districts in Indonesia which is also said to be a paradise chip island. How not, this regency can be mentioned as a thousand monument district. From the beginning we entered the Samosir Regency area, we can see that along the road leading to the Samosir Regency area, the view that was offered to us who just set foot in Samosir Regency is arid land and in some places there are agricultural land residents. In addition, the development and magnificent monuments and simin in left and right of the road that we passed and beautiful scenery if we look towards Lake Toba.

The Regency, which is surrounded by Lake Toba, shows its characteristics as a

unique Regency. In other areas it is very rare or even almost a monument to respect the spirits of the ancestors. In Samosir Regency, it is very easy to find monuments of the clan 
or simin which are useful as a means of unifying clans and to respect the spirits or spirits of ancestors. Along the road to Pangururan and Palipi Sub-dstrict it can be observed that almost every Batak Toba house has built Simin in front of or behind the yard of his house. This proves that Toba Batak tribe highly respects their ancestors.

Samosir Regency deserves its nickname as the "Thousand Monument" Regency. In almost every area, clan groups in Samosir Regency have built monuments which cost hundreds of millions or even billions of rupiah. Do not hesitate, the people of Samosir Regency, especially for the clans who want to build their monument, in collaboration with its members to build a monument in the area that has been determined based on joint decisions. This is done to maintain the territorial boundaries of a clan. As revealed by Oktavia Sitohang. Oktavia Sitohang is one of the descendants of the King Sitohang who lives right next to the Sitohang clan monument with the straightforward expressing as follows:

"In the development of a monument here, our Toba Batak people here consider the area. For example in the Sitohang clan area, now the people who live here are only people with the surname Sitohang. So although there are those who want to buy land in the Sitohang clan area, the customary leaders here do not allow the land to be sold. The land has been considered as customary land ".

The same thing was expressed by Mardin Siregar (Ompu Samuel Siregar). Mardin Siregar (Ompu Samuel Siregar) is one of the residents living in the Raja Sitohang area whose wife is from the Sitohang clan. The following is an excerpt from the results of the interview:

"The development of a monument that is made almost in every clan in Samosir Island has its own characteristics. Where the members of the clan occupy their territory that's where they build a monument. The development of the monument was not of origin built but with the development of the monument, it was hoped that it would strengthen the brotherhood among fellow clan members. In addition, the development of the monument will also prove where the clan population itself. "

Aside from the process of building a monument, there is something very interesting to know in depth about the death of Toba Batak people in Samosir Regency, namely the return of Toba Batak community to their homeland when they reach old age and even when they have died. Every old Batak person will ask to return to his hometown, Samosir Regency. They will leave their children and grandchildren to bury them in their native land, namely in Samosir Regency. Although there are clans that have been born outside the region, but they also have the will to bury them in Samosir Regency when they die later. This is a proof of their love for Toba Batak land which is always told by their elders.

Every day there will always be ferry shipping that provides a special place for the "Ambulance" corpse car. Each time a car that fits in the ferry is forty (40) cars. As many as 39 cars will be put in a car containing ordinary passengers and for one place the car is left for Ambulance. This is as explained by Ramod Sirait as one of the ferry shipping officers from Ajibata Port to Tomok Port said as follows:

"We here always provide a special place for Ambulance, which is usually we always cross the bodies to Samosir Island. We are loading here in one trip, that is 40 cars. 39 for us to drive the cars of ordinary passengers and the only one we leave for the Ambulance car. And if it is averaged in every day the crossing route there are two Ambulance cars carrying bodies to be buried by the family on Samosir Island ".

The same thing was expressed by Mardin Siregar (Ompu Samuel Siregar). The following is an excerpt from the results of the interview: 
"Yes, it is very good what has been made by the crossing and shipping vessels. Because they make it easier for us to bring dead bodies from Parapat to Samosir Island. Usually in other places it is very difficult for us to cross bodies to, especially using an Ambulance car.

Based on the results of interviews and observations conducted in the field shows that Toba Batak community and Ferry ferry crossing work together to facilitate the process of bringing bodies from outside the city to Samosir Regency. Every day at least two hearses will surely enter the Samosir Regency. The people of Samosir Regency have never rejected a corpse or corpse brought from outside Samosir Regency. In addition, Toba Batak community in Samosir Regency also never quoted contributions or special payments for funerals made by Samosir Regency. As expressed by Nermika Pandiangan as follows:

"Everyone who brings a corpse here will not have wild quotes carried out here. We accept all of our society. Our clan, especially the same clan. People who die outside who are brought here to be buried will not be rejected by our society here. As long as he is a member of our clan in Samosir Regency. Even though he was not born in Samosir Regency, but if he is a descendant of the clan in Samosir Regency, our community will never be rejected here ".

In addition to what was conveyed by Nermika Pandiangan, the same thing was stated by Raida Siringo-Ringo (Ompu Riri Boru Siringo-Ringo) as follows:

"Every Toba Batak community who dies outside Toba Batak area will be sent back for burial and simin production. Now on its way to here our people who will not quote quotes here or contributions to families who have died. If he is one of our clan members here, we will instead help to carry out the traditional funeral process. "

Based on the statements of the informants above, it is shown that the people of Samosir Regency always accept the bodies that were brought by their family members from outside the area to Samosir Regency to be buried and buried. The community will not take advantage in any form, including contributions as a place for burial. The people of Samosir Regency gladly accepted and even helped in the funeral process that would be carried out by the family left behind by the corpse. The bond of kinship between the Batak people is very harmoniously interwoven. The family of the corpse respects the residents and the local community by feeding the community around the burial site as a sign of respect.

In addition, in the process of building a monument, Toba Batak people in Samosir Regency, especially in Pangururan and Palipi Sub-district, built simin and monuments as a form of respect for the spirits of the ancestors who had preceded them. In the process of mangongkal holi or the process of removing the bones of the ancestors of Toba Batak clan is carried out on a large scale with traditional ceremonies. If a family member dies and has been buried outside Samosir Regency, the bones will be removed during the panakkok saring ceremony.

The development of the monument in Samosir Regency proves that the Regency of Samosir is worthy to be mentioned as the Regency of Thousand Monuments. This is due to the large number of monuments that have been erected by clans that occupy the Samosir Regency, especially in Pangururan and Palipi Sub-district. The number of monuments and the number of monuments in the form of simins is very much encountered along the road in the Samosir Regency. Society has formed medium-sized simin to respect its melting spirits.

The Simin development was carried out by the Toba Batak community, Samosir Regency was carried out consciously by Toba Batak community. With the development of the simin they hope that the spirits of the ancestors occupy a beautiful place in nature that 
is different from the nature occupied by humans during their lives. The existence of special forms of treatment of their offspring is a form of care for their offspring for ancestral spirits. In addition, similing is also done to get blessings from the ancestors and to be prayed for by the ancestors to their living descendants.

There are so many public opinions regarding the development of monument carried out by the Batak Toba community in Samosir Regency. However, the development of this monument is inseparable from two aspects, namely in terms of religion / belief and cultural aspects. The development of a monument that is so fierce in Samosir Regency carries so many meanings behind the monument itself. The number of parsadaan monuments in Samosir Regency is 19 , which can be seen in the following figure:

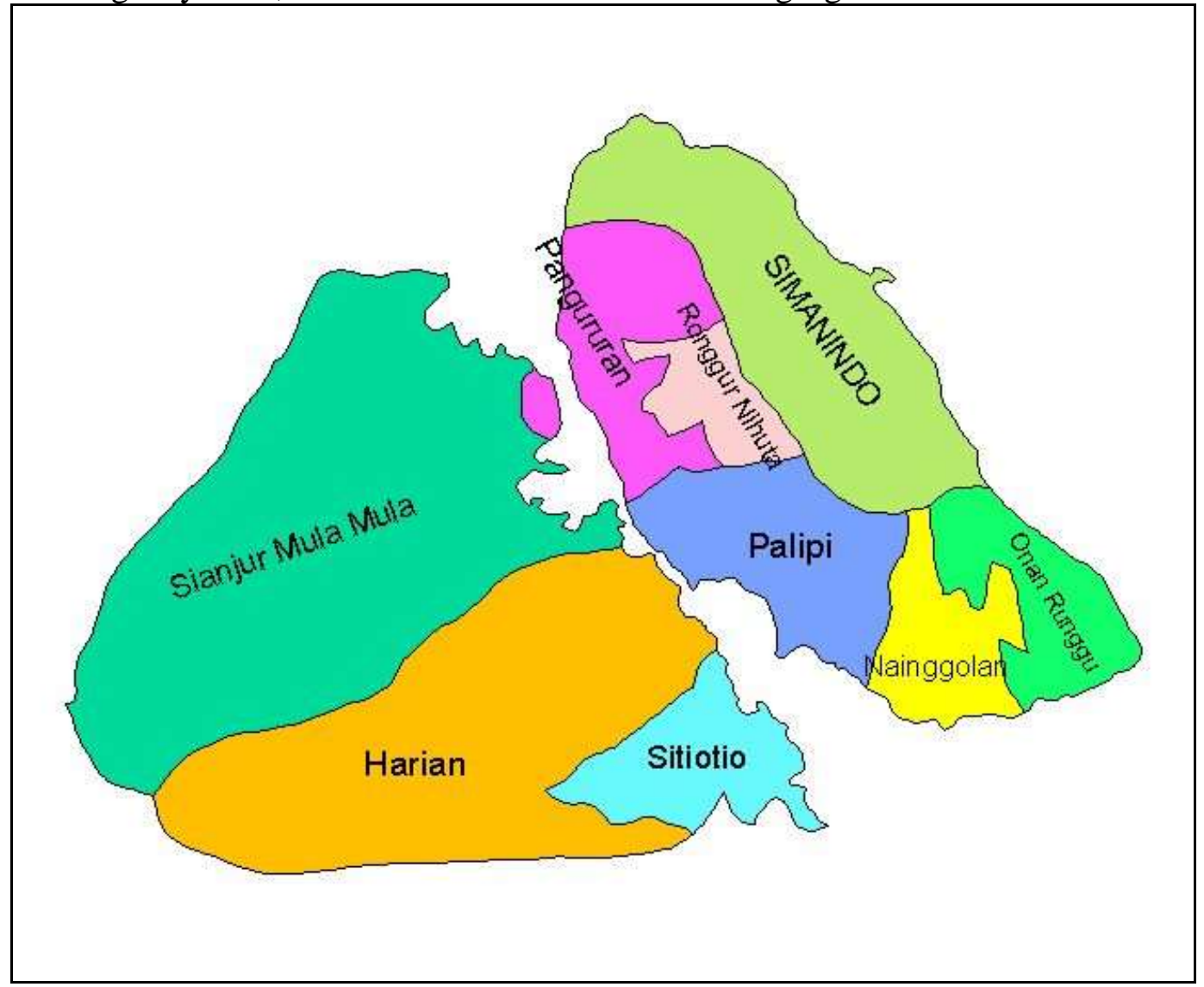

Figure 1. The number of monuments in each sub-district

\section{Information:}

: Manik Monument

: Siringo-Ringo Monument

: Sinaga Monument

Situmorang Monument

Pandiangan Monument

Sitohang Monument

The objects of the study 


$$
\begin{aligned}
& \text { : Sitanggang Monument } \\
& : \text { Simbolon Monument } \\
& \text { : Sitinjak Masiolan Monument } \\
& \text { : Gultom Mongolan Monument } \\
& \text { : Samosir Monument } \\
& \text { : Pak-pahan Monument } \\
& \text { : Limbong Monument } \\
& \text { : Sihotang Monument } \\
& \text { : Tamba Monument }
\end{aligned}
$$

Based on the results of the mapping of the parsadaan monuments above, it shows that Samosir Regency is a regency that has many monuments of persadaan. The most monuments in Samosir Regency are Pangururan Sub-district with 4 monuments namely Naibaho monument, Situmorang monument, Manik monument and Simbolon monument. While what has been studied in Pangururan sub-district are Manik monument and Situmorang monument. Palipi monument of persadaan are Siringo-ringo monument, Sinaga monument, Sitohang monument, Sitanggang monument and Pandiangan monument. While there are 4 units studied, namely Siringo-Ringo Monument, Sinaga Monument, Sitohang Monument and Pandiangan Monument. The researcher's basic consideration is to choose the six monuments which are used as the focus of research in Pangururan and Palipi sub-districts because in these two regions the phenomenon of monument development is unique and the existing monuments have different models, ornaments and forms. This has attracted the attention of researchers to examine the phenomena and meaning of the development of monuments in particular in the two regions and is a representation of the monuments found in Samosir Regency. Besides that in these two sub-districts it was found that most of the magnificent and luxurious parsenence monuments were built.

\section{Conclusion}

There are so many public opinions regarding the development of the monument carried out by Batak Toba community in Samosir Regency. However, the development of this monument is inseparable from two aspects, namely in terms of religion / belief and cultural aspects. The development of a monument that is so fierce in Samosir Regency 
carries so many meanings behind the monument itself. The number of parsadaan monuments in Samosir Regency is 19.

Samosir Regency is a regency that has many monuments of persadaan. The most monuments in Samosir Regency are Pangururan Sub-district with 4 monuments, Naibaho monument, Situmorang monument, Manik monument and Simbolon monument. While what has been studied in Pangururan sub-district are Manik monument and Situmorang monument. In Palipi Sub-district, the monuments of persadaan are Siringo-ringo

monument, Sinaga monument, Sitohang monument, Sitanggang monument and Pandiangan monument.

\section{References}

Aditjontro, GJ. 2004. Kisah Daud melawan Goliath Di Pedalaman Tanah Batak. Medan: Bakungsu.

Agger, Ben. 2013. Teori Sosial Kritis, Jakarta: Kreasi Wacana.

Batara Sangti, 1997. Adat dan Budaya Batak. Medan: Monora

Ball, Van. 1976. Sejarah Dan Filsafat Antropologi Jilid I dan II. Jakarta: Gramedia.

Barth, Fredrick, 1986. Kelompok Etnik dan Batasannya, Jakarta: UI-Press.

Campbell, Tom. 1994. Tujuh Teori Sosial, Sketsa, Penilaian, Perbandingan. Yogyakarta. Penerbit Kanisius.

Castles, Lance. 2001. Kehidupan Politik Suatu Kepresidenan di Sumatera: Tapanuli 19151940. Jakarta: Gramedia.

Creswell, J W. 1998. Qualitative Inquiry and Reseasch Design: Choosing Among Five Traditions. USA: Sage Publication

Danim, Sudarwan. 2002. Menjadi Peneliti Kualitatif. Jakarta: Pustaka Setia.

Dede, Mulyanto, 2014. Pemikiran Antropologi. Jakarta: Marjin Kiri.

Durkheim, E. 1964. The Division of Labour in Society, (terjemahan George Simpson), New York: The Free Press.

Evans - Pritarchad, E. E, 1986. Antropologi Sosial (alih bahasa: Nancy Simanjuntak), Surabaya: BumiAksara

Furchan. Arief, 1992. Metode Penelitian Kualitatif, Surabaya: Usaha Nasional

Garna, Judistira K. 1992. Teori-Teori Perubahan Sosial, Bandung: PPS - UNPAD

Gerzt, Clifford. 1973. The Interpretation of Cultures. New York: Basic Books

Giddens, A. 1985. Kapitalisme dan Teori Sosial Modern, Jakarta: UI-Press

Gultom, J. 1992, Dalihan Na Tolu Nilai Budaya Suku Batak, Medan: Firma Hasmar.

Hans-dieter, Evers, 1988. Teori Masyarakat Proses Peradaban Dalam Sistem Dunia Modern, Jakarta: Yayasan Obor.

Hartoko. Dick, 1984. Manusia dan Seni. Yogyakarta. Kanisius.

Ihromi, T. O, 1987. Pokok - Pokok Antropologi Budaya, Jakarta: Gramedia.

Kartini, 1983. "Asosiasi Klan Orang Batak Toba di Jakarta”. Dalam Prisma No. 1 Tahun XII. Jakarta: LP3ES.

Kuswarno, Engkus, 2009. Metodologi Penelitian Komunikasi, Fenomenologi Konsepsi, Pedoman dan contoh Penelitian. Bandung: Widya Padjdjaran

Lajar, A.B. 2005. "Jaques Derrida dan Perayaan Kemajemukan", dalam Mudji Sutrisno \& Hendar Putranto (ed). Teori-teori kebudayaan. Yogyakarta: Kanisius

Lauer, R. H, 1993. Perspektif Tentang Perubahan Sosial, (terjemahan), Jakarta: Bina Aksara.

Malau Ismail, 1985. Mengenal Batak, Medan: CV. Kiara. 
Malinoski, B. 1983. Dinamika Bagi Perubahan Budaya, Kuala Lumpur: Adabsi SDN. BHD.

Murdock, Peter, George. 1949. Social Structure. London: The Free Press.

Nababan, S.A.E. 1994. Mencari Keseimbangan. Jakarta: Sinar Harapan.

Nainggolan, Togar. 2012. Batak Toba di Jakarta Kontiunitas dan Perubahan Identitas. Medan: Bina Media Perintis.

Ogburn, W. F, 1986. Ketertinggalan Kebudayaan, Jakarta: Rajawali Press.

Parlindungan, O. M, 2007. Tuanku Rao. Yogyakarta: LKIS.

Pasaribu B. John. 2002. Pengaruh Injil Dalam Adat Batak, Jakarta. Sinar Harapan.

Pritchard, EE. Evans. 1986. Antropologi Social. Jakarta: Bumi Aksara.

Radcliffe - Brown, AR. 1979. Structure and Fungtion Primitive Society. London: Routledge and Kegan Paul.

Reid, Anthony, 2002. Pulau Orang Meninggal, Mengapa Orang Batak Membangun Monument. Medan: Bina Media Perintis.

Schutz, Alfred. 1973. The Phenomenology of the Social World. London: Heineman Education Book.

Taylor, J. Steven. 1975. Introduction to Qualitative Research Methods. London: John Wiley \& Son.

Uli, Kojok. 2009. Surat Batak: Sejarah Perkembangan Tulisan Batak. Jakarta: Gramedia.

Yudosaputro, 1993. Wawasan Seni Budaya. Jakarta: Pusat Perbukuan Depdikbud.

Vera, Nawiroh. 2014. Semiotika dalam Riset Komunikasi. Jakarta: Ghalia Indonesia.

Vergouwen. J.C. 2004. Masyarakat dan Hukum Adat Batak Toba. Yogyakarta: LkiS.

Warneck, 1873. Nacht en Morgen op Sumatra Schetsen en Verbalen, Amsterdam: Hoveker \& Zoon.

Zaprulkhan, 2015. Filsafat Ilmu Sebuah Analisis Kontemporer. Jakarta, Rajawali Press.

Zenkins, Rechard. 2008. Identitas Sosial. Jakarta: Bina Media. 